\title{
TEKNOLOGI PROSES PENGECATAN MENGGUNAKAN SISTEM ATOMISASI PADA PRODUK BERBAHAN PLASTIK DI INDUSTRI PERAKITAN SEPEDA MOTOR
}

\author{
Nur Islahudin \\ Program Studi Teknik Industri, \\ Fakultas Teknik Universitas Dian Nuswantoro \\ Jl Nakula I No 5-12, Semarang 50131 \\ E-mail: nur.islahudin@dsn.dinus.ac.id
}

\begin{abstract}
ABSTRAK
Sepeda motor merupakan jenis alat transportasi yang cukup familiar di Negara Indonesia. Harga terjangkau serta kecepatan untuk mobilisasi menjadi alasan utama pemilihan jenis transportasi ini. Permintaan kebutuhan sepeda motor yang masih cukup besar di Indonesia mendorong industri manufaktur perakitan sepeda motor berusaha selalu menghadirkan produk-produk sesuai dengan kebutuhan konsumen. Untuk dapat memenuhi kebutuhan konsumen yang bervariasi, produsen sepeda motor selalu melakukan perbaikan diseluruh bagian produksi nya. Terdapat dua komponen utama dalam sepeda motor yaitu engine dan frame. Dua komponen ini diproduksi oleh beberapa bagian produksi berdasarkan karakteristik dari masing-masing produk. Bagian produksi dari industri perakitan sepeda motor yang melakukan kegiatan pengecatan pada produk berbahan plastik adalah bagian painting plastik. Teknologi pelapisan yang digunakan bagian painting plastik adalah teknologi atomisasi. Teknologi ini merupakan teknologi pelapisan dengan cara merubah cairan material menjadi kabut atau butiran yang digunakan untuk melapisi produk. Teknologi ini mempunyai banyak kendala dari segi transfer material ke produk. Pemilihan material yang tepat menjadi kunci dari proses atomisasi, selain itu faktor manusia juga menjadi penting karena kompetensi atau keahlian operator saat proses pengecatan dapat mempengaruhi hasil produk. Dari permasalahan tersebut penulis berusaha memetakkan beberapa permasalahan yang dihadapi oleh bagian painting antara lain material technology, sistem produksi, kualitas produk serta masalah-masalah yang ditimbulkan dari proses pengecatan terhadap lingkungan. Namun dengan tingkat kompleksitas masalah yang dihadapi bagian painting plastik tersebut, belum banyak penelitian yang fokus terhadap permasalahan pada proses pengecatan produk berbahan plastik. Oleh karena itu penulis mencoba memberikan gambaran secara rinci tentang proses produksi pada bagian painting plastik. Penulis membagi artikel ini menjadi beberapa sub bab antara lain paintingtechnology, technology material, production system dan Quality properties. Selanjutnya penulis berharap artikel ini dapat digunakan sebagai dasar untuk pengembangan proses pengecatan pada produk berbahan plastik.
\end{abstract}

Kata kunci : atomisasi, pengecatan, material cat

\section{ABSTRACT}

Motorcycles are a type of transportation that is familiar in Indonesia. Cost product and speed for mobilization are the main reasons for choosing this transportation. Demand for motorcycles that are still large in Indonesia and encouraged motorcycles manufacturing industries to deliver products according to consumer needs. To be able to meet the varied needs of consumers, motorcycle manufacturers always make improvements in all of their production area. There are two main components in the motorcycle, engine and frame. These two components are produced by several parts of production based on the characteristics of each product. The production section of the motorcycle industry that do paintingactivities on plastic products is painting plastic section. The coating technology used in painting plastic is atomization. This technology is a converting liquid material into mist or 
granules used to coat the product. This technology has many challenges in terms of material transfer to products. The selection of the right material is the key to the atomization process, besides that human factors are also important because the operator's competence or expertise during the painting process can affect product yield. From these problems the author tries to map some of the problems caused by paintings, including technological materials, production systems, product quality and problems caused by painting processes to the environment. However with the level of complexity of the problems faced by the plastic paintingsection, not many studies have focused on the problems in the paintingprocess of plastic products. Therefore the author tries to give a detailed description of the production process in the painting plastic section. The author divides this article into several sub-chapters including paintingtechnology, technology material, production system and Quality properties. Furthermore, the authors hope that this article can be used as a basis for developing the paintingprocess on plastic products.

Keywords: atomization, painting, paint

\section{PENDAHULUAN}

Sepeda motor masih menjadi pilihan utama sebagai alat transportasi masyarakat Indonesia saat ini. Harga terjangkau serta kecepatan saat mobilisasi menjadi alasan utama masyarakat Indonesia memilih jenis transportasi ini. Data penjualan sepeda motor di Indonesia 10 tahun terakhir menunjukan adanya kenaikan produksi yang cukup signifikan [Gambar 1.]. Selain itu dilihat dari data rasio kepemilikan sepeda motor di Indonesia yang masih rendah dibanding dengan negara lain. Pada tahun 2014 rasio kepemilikan sepeda motor di Indonesia sebesar 1:3 yang artinya satu unit sepeda motor digunakan oleh tiga orang [1], sehingga masih cukup besar peluang pasar untuk produksi sepeda motor di Indonesia. Namun cukup besar tantangan yang dihadapai para produsen sepeda motor antara lain perubahan permintaan konsumen yang sangat cepat serta ketidak pastian permintaaan dari konsumen membuat para produsen sepeda motor harus dapat melakukan perbaikan secara menyeluruh di bagian produksi agar dapat memenuhi tantangan tersebut.

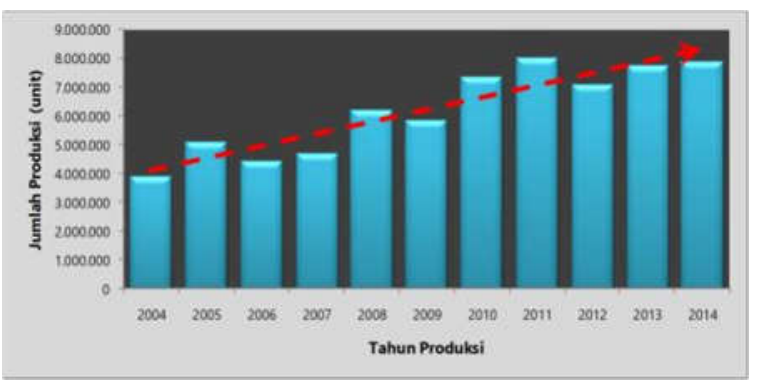

Gambar 1. Jumlah produksi sepeda motor di Indonesia (Sumber: Asosiasi Industri Sepeda motor Indonesia)
Sepeda motor secara umum dibagi menjadi dua komponen utama yaitu engine dan frame. Komponen engine merupakan komponen pembentuk engine sepeda motor seperti crank case, crank shaft, cylinder comp, head comp, gear counter, dan beberapa komponen pendukung lainnya. Sedangkan komponen frame merupakan komponen pembentuk kerangka dari sepeda motor yang terdiri dari dua sub komponen yaitu komponen yang berbahan logam (steel product) dan komponen berbahan plastik (plastic product). Komponen-komponen tersebut umumnya diproduksi oleh bagianbagian berdasarkan karakteristik dari proses manufaktur komponen tersebut. Gambaran proses manufaktur di industri perakitan sepeda motor dapat dilihat pada gambar 2 .

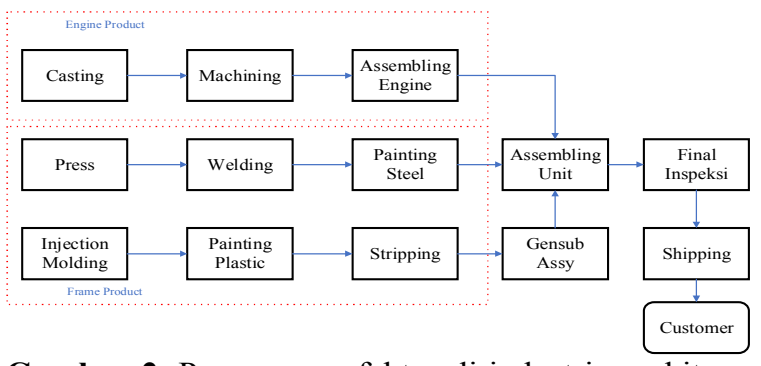

Gambar 2. Proses manufaktur di industri perakitan sepeda motor

Setiap bagian dari proses manufaktur mempunyai tingkat kesulitan yang berbeda tergantung dari karakteristik dari produk yang di produksi. Tingkat kesulitan dari proses manufaktur dapat diukur melalui beberapa evaluasi dari hasil produksi proses tersebut, Evaluasi yang sering di terapkan dalam proses produksi di industri perakitan sepeda motor adalah QCDSM performance. Metode ini digunakan untuk mengukur kinerja proses produksi dari beberapa aspek yaitu quality, cost, 
delivery, safety dan moral. Salah satu aspek evaluasi proses produksi yang dapat mempengaruhi secara langsung biaya produksi suatu produk adalah aspek biaya (cost). Aspek ini menjadi salah satu aspek prioritas untuk evaluasi proses produksi di industri perakitan sepeda motor. Contoh evaluasi aspek biaya dalam industri perakitan sepeda motor adalah biaya untuk spoilage/cruser produk yang tidak bisa digunakan kembali (remanufacturing). Contoh proporsi biaya spoilage yang dikeluarkan oleh masing-masing bagian produksi di industri perakitan sepeda motor dapat dilihat pada gambar 3 .

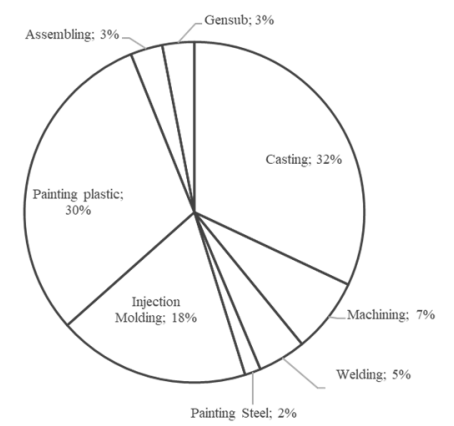

Gambar 3. Biaya spoilage per bagian di industri perakitan sepeda motor (Sumber: Astra Honda Motor)

Secara data spoilage di atas, bagian produksi yang mempunyai biaya terbesar untuk spoilage adalah bagian casting dan bagian painting plastik. Proses casting mempunyai beberapa kendala terkait dengan permasalahan yang terjadi setelah proses machining sehingga produk yang sudah melalui proses machining tidak dapat digunakan kembali untuk recasting. Sedangkan proses painting plastik mempunyai beberapa kendala yang berhubungan dengan material, technology, equipment dan sistem pengendalian kualitas yang mempengaruhi hasil dari proses pengecatan. Selain itu terdapat permasalahan yang berhubungan dengan Remanufacturing untuk proses pengecatan hanya boleh dilakukan sebanyak dua kali dari raw material plastik. Oleh karena itu setelah produk mengalami pengecatan sebanyak dua kali, apabila terjadi defect kembali produk akan menjadi spoilage. Artikel ini akan secara khusus membahas tentang proses painting plastik pada industri perakitan sepeda motor.

Painting plastik merupakan satu proses manufaktur di industri perakitan sepeda motor yang melakukan kegiatan pengecatan untuk membuat variasi warna cover sepeda motor yang berbahan plastik. Proses pengecatan mempunyai beberapa fungsi antara lain fungsi dekoratif dan fungsi protektif. Fungsi dekoratif bertujuan untuk memperindah produk serta meningkatkan nilai estetika dari produk yang telah dicat. Sedangkan fungsi protektif bertujuan untuk melindungi produk dari kerusakan yang disebabkan oleh cuaca, lingkungan dan bahan kimia. Proses pengecatan pada produk berbahan plastik mempunyai kesulitan karena beberapa faktor antara lain faktor teknis dan faktor ekonomi. Dari segi teknis produk berbahan plastik mempunyai fisik permukaan yang halus dengan pori permukaan yang kecil sehingga sulit untuk di lapisi. Oleh karena itu proses pengecatan pada produk berbahan plastik harus menggunakan material yang sesuai dengan karakteristik fisik dari bahan plastik, apabila tidak sesuai cat akan mudah mengelupas (peel off) dari permukaan produk. Hal ini disebabkan karena material cat tidak dapat merekat sempurna pada permukaan produk. Sedangkan dari segi ekonomi ongkos material cat yang dibutuhkan untuk proses pengecatan mewakili $50 \%$ dari keseluruhan ongkos produksi yang dikeluarkan oleh bagian painting [2]. Hal ini berarti pemakaian material cat menjadi parameter utama untuk mengendalaikan ongkos produksi bagian painting.

Dari beberapa kendala yang dihadapi oleh bagian painting plastik, penulis menemukan masih sedikit rerferensi yang membahas tentang permasalahan-permasalahan pada bagian painting plastik. Oleh karena itu penulis mencoba untuk memberikan gambaran secara umum tentang proses pengecataan pada produk berbahan plastik agar dapat digunakan untuk pengembangan proses pengecatan pada produk berbahan plastik. Penulis membagi artikel ini menjadi beberapa sub bab pembahasan antara painting technology, material technology, production system, quality properties.

\section{METODE PENELITIAN}

Salah satu metode pengecatan yang digunakan untuk pengecatan produk berbahan plastik adalah metode Spray atomisasi. Metode ini saat ini merupakan salah satu metode terbaik yang digunakan untuk melapisi permukaan produk berbahan plastik. Metode ini secara 
konsep mengubah suatu fluida menjadi partikel berukuran micron. Ukuran partikel yang sangat kecil dapat menghasilkan tingkat kilapan (gloss) permukaan produk yang lebih baik. Selain itu partikel yang berukuran micron akan mudah masuk ke dalam pori - pori bahan plastik yang sangat kecil sehingga cat dapat merekat ke permukaan produk. Proses terjadinya partikel dalam atomisasi disebabkan karena adanya pemecahan atau pembentukan fluida menjadi partikel oleh kecepatan udara. Bagian sistem atomisasi yang mengatur pemecahan fluida menjadi partikel adalah nozzle (gambar 4).

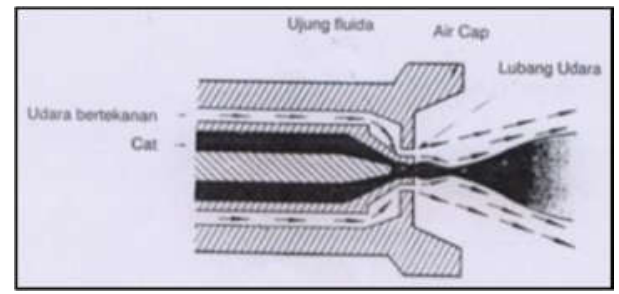

Gambar 4. Sistem Atomisasi dengan nozzle

Metode Spray atomisasi untuk pengecatan produk berbahan plastik mengalami perkembangan dalam hal sistem operasinya dari yang manual sampai dengan otomasi menggunakan robot. Sistem atomisasi proses pengecatan yang paling sering digunakan adalah dengan sistem operasi manual menggunakan Spray gun (gambar 5\&6). Metode pengecatan ini mempunyai beberapa kelebihan antara lain mampu menjangkau produk yang mempunyai banyak lekukan serta area yang sulit dijangkau oleh robot Spray. Namun metode ini juga mempunyai beberapa kekurangan yaitu ketidak stabilan hasil pengecatan karena menggunakan system operasi manual yang dikerjakan oleh manusia. Selain metode atomisasi Spray menggunakan system operasi manual, pengecatan di industri perakitan sepeda motor sudah menerapkan teknologi pengecatan electrostatic Spray menggunakan e-Spray gun dan bell rotary pada robot Spray (gambar 8). Metode electrostatic merupakan metode baru yang diaplikasikan untuk pengecatan produk berbahan plastik karena dapat meningkatkan efisiensi pemakaian material cat sampai (50-60)\% dibandingkan Spray manual yang hanya mempunyai efisiensi sebesar (20-30)\% [3]. Konsep teknologi electrostatic adalah dengan memberikan muatan listrik negatif pada material cat dan muatan listrik positif pada produk sebagai grounding sehingga cat akan menempel ke permukaan produk sesuai dengan prinsip muatan listrik dapat berpindah dari benda yang bernilai negative ke benda yang bernilai positive (gambar 9)[4]. Perbedaan proses pengecatan menggunakan electrostatic dan manual Spray terletak pada material yang digunakan. Untuk proses manual Spray jenis material yang digunakan tidak menspesifikasi tentang hambatan yang ada di material cat sedangkan untuk proses electrostatic mempunyai spesifikasikan nilai hambatan material cat sebesar $(0,3-1,0) \mathrm{M} \Omega$.
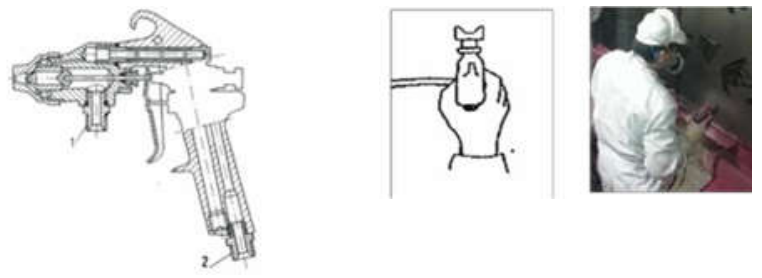

Gambar 5. Manual Spraygun (1. Paint supply, 2. Compresed gas supply)

Gambar 6. Proses pengecatan menggunakan Spraygun
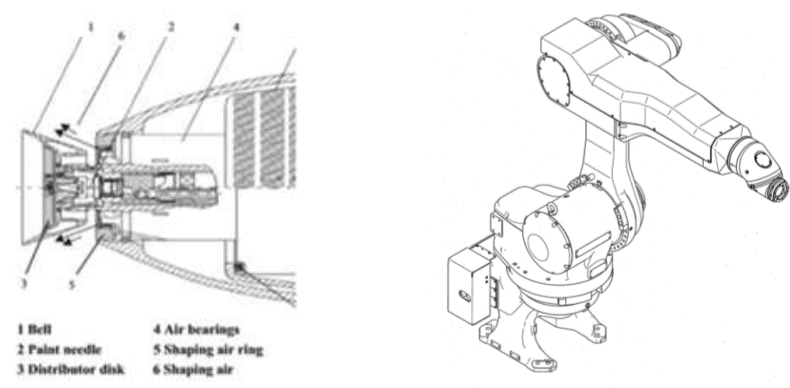

Gambar 7. High speed Rotary bell untuk Robot Spray

Gambar 8. Robot Spray Painting

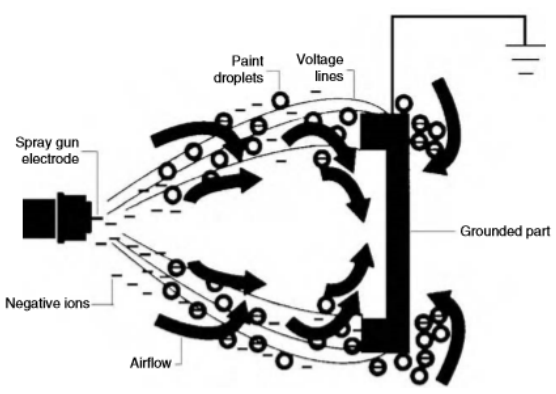

Gambar 9. Interaksi dalam proses electrostatic spray

Selain spesifikasi material yang berbeda proses pengecatan electrostatic pada produk berbahan 
plastik membutuhkan conductive pada permukaan produk karena sifat isolator produk berbahan plastik. Oleh karena itu sebelum proses electrostatic permukaan produk berbahan plastik dilapisi terlebih dahulu material conductive. Lapisan ini bertujuan untuk membuat material plastik mempunyai sifat conductor saat proses electrostatic sehingga material cat dapat menempel ke permukaan produk berbahan plastik.

\subsection{Material Teknologi}

Pemilihan material untuk pengecatan produk berbahan plastik menjadi penting karena beberapa faktor terkait fungsi adhesive material cat ke permukaan produk. Pemilihan material cat yang salah akan berdampak terhadap kualitas hasil pengecatan. Pada bagian ini pembahasan tentang material lebih diarahkan pada komposisi dari material yang digunakan untuk pengecatan produk berbahan plastik. Salah satu jenis material cat yang sering digunakan untuk pengecatan pada bahan plastik adalah material yang mempunyai sifat thermosetting yaitu material yang proses pembentukan lapisan ataupun ikatannya dilakukan dengan cara pemanasan. Dengan kata lain proses pembentukan lapisan film membutuhkan waktu untuk curing dalam temperature dan waktu tertentu. Salah satu jenis cat yang digunakan untuk pengecatan produk berbahan plastik adalah jenis cat polyurethane. Berikut ini komposisi material cat yang digunakan untuk pengecatan produk berbahan plastik.

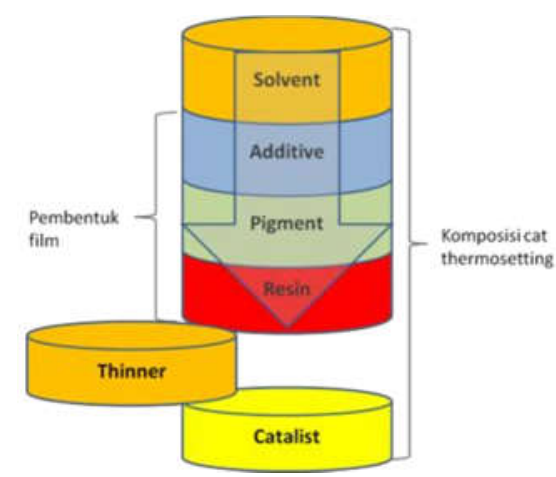

Gambar 10. Komposisi material cat jenis polyurethane (thermosetting)

Dari gambar di atas kompsisi material cat jenis polyurethane dapat dibagi menjadi beberapa komponen antara lain :

\section{a. Solvent}

Solvent merupakan cairan yang terdiri dari satu ataupun dua komponen yang dapat mengering dalam kondisi tertentu dan mampu melarutkan komponen pembentuk lapisan film secara fisik tanpa melalui proses kimia. Solvent terdiri dari beberapa jenis / gugus yang memunyai sifat fisik dan kimia tertentu. Pemilihan jenis solvent untuk pembuatan material cat dapat mempengaruhi proses pembentukan film saat proses pengecatan. Beberapa faktor yang digunakan untuk pertimbangan pemilihan jenis solvent untuk material cat antara lain daya larut, boiling point, flash point dan biaya.

Daya larut menjadi faktor utama dalam pemilihan solvent hal ini disebabkan karena daya larut dapat mempengaruhi proses produksi dari pembuatan material cat. Solvent digunakan untuk proses pencampuran bahan pembentuk cat, sehingga solvent yang mempunyai daya larut yang baik akan mempermudah proses pencampuran bahan pembentuk material cat, namun terdapat beberapa permasalahan yang terjadi karena pemilihan solvent yang mempunyai daya larut tinggi mempunyai kecepatan penguapan yang rendah. Kecepatan penguapan yang rendah akan berdampak terhadap hasil proses pengecatan, solvent yang mempunyai kecepatan penguapan akan mempersulit proses atomisasi material cat. Solvent yang mempunyai kecepatan penguapan yang rendah akan menghasilkan butiran atomisasi lebih kasar sehingga berakibat butiran yang menempel ke permukaan produk menjadi kasar yang dapat mempengaruhi kualitas produk hasil pengecatan.

\section{b. Resin / Binder}

Resin ini merupakan komponen utama pembentuk cat. Jenis dari resin inilah yang mempengaruhi sifat dan kualitas cat. Resin secara umum dibagi menjadi dua :

- Natural resin

Resin yang terbuat dari bahan-bahan alami seperti kacang kedelai, kelapa sawit, beras dan sebagainya.

- Sintetis resin

Resin yang terbuat dari bahan sintetis misal acrylic. 


\section{c. Pigmen}

Pigmen merupakan padatan dalam cat yang didispersikan untuk memberikan karakteristik tertentu seperti warna, opacity, daya tahan, kekuatan mekanik, serta perlindungan korosi pada material cat [4]. Pigmen ini sangat erat kaitannya dengan daya tutup material cat hal ini berarti pemilihan dan kandungan pigmen material cat mempengaruhi daya tutupnya. Cat yang mempunyai kandungan pigmen yang banyak akan mempunyai daya tutup yang baik. Proses pengecatan pada produk berbahan plastik sangat memerlukan daya tutup (hiding power) dari suatu material cat karena sifat ini mempengaruhi proses dan hasil dari pengecatan produk berbahan plastik.

Berdasarkan fungsinya pigmen dibagi menjadi tiga yaitu :

- Color pigmen : sebagai pemberi warna dan daya tutup

- Filler pigmen : sebagai pengisi, umumnya untuk warna dasar dan dempul

- Anti Korosi pigmen : digunakan untuk pelindung benda dari korosi.

\section{d. Additive}

Merupakan sebuah bahan kimia yang digunakan sebagai penyempurna performa cat, masing-masing additive mempunyai sifat dan fungsi yang berbeda-beda. Additive digunakan untuk mempermudah proses pengecatan, penyimpanan dan kualitas dari film hasil pengecatan. Beberapa contoh additive yang sering digunakan untuk proses pengecatan produk berbahan plastik adalah additive anti foam, anti sagging, additive untuk mencegah pengendapan cat dan lain sebagainya.

\section{e. Thinner}

Thinner merupakan komponen material cat yang terdiri dari beberapa gabungan dari solvent. Berbeda dengan solvent fungsi dari thinner lebih digunakan saat proses pengecatan ke produk, bukan untuk produksi material cat. Selain itu thinner ini mempunyai fungsi untuk mempermudah proses pelapisan cat dengan mengatur kecepatan penguapan cat supaya mudah melapisi permukaan produk. Thinner merupakan kumpulan beberapa solvent yang mempunyai sifat-sifat tertentu seperti nilai boiling point, solubility, flash point . Salah satu parameter dari thinner yang sering digunakan untuk melihat kualitas dari thinner adalah nilai boiling point. Boiling point merupakan salah satu parameter yang mengukur temperature penguapan dari thinner tersebut. Semakin cepat thinner tersebut menguap berarti thinner tersebut terbentuk dari solvent yang mempunyai boiling point rendah.

\section{f. Catalist / Hardener}

Catalyst atau hardener merupakan komponen dari material cat yang berfungsi sebagai pengeras saat proses pengeringan setelah proses Spray. Catalyst diperlukan untuk pengeras karena jenis material cat yang digunakan adalah jenis thermosetting. Jenis material ini membutuhkan pengikat untuk proses pengerasan yang bereaksi terhadap panas.

\subsection{Sistem Produksi}

Proses produksi pada bagian painting plastik umumnya menggunakan beberapa rangkaian alat yang digabungkan menjadi satu kesatuan dan mempunyai fungsi yang berbeda. Keseluruhan rangkaian dari alat tersebut dihubungkan dengan konveyor untuk media transfer produk yang akan di cat. Gambaran proses produksi bagian painting plastik dapat dilihat pada gambar 11.

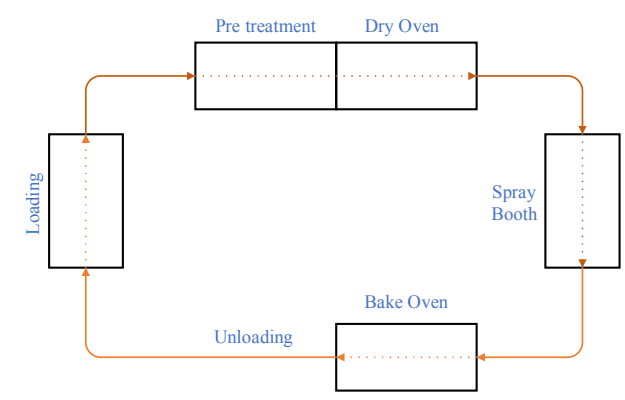

Gambar 11. Flow proses produksi painting plastik

\section{a. Loading}

Loading merupakan salah satu proses kegiatan dalam system produksi bagian pengecatan yang mempunyai tujuan untuk menaikkan produk plastik yang masih raw material ke konveyor system pengecatan. Proses ini merupakan proses awal dari rangkaian proses pengecatan, sehingga penentuan perencanaan produksi dari bagian production planning digunakan untuk acuan pola produksi proses ini. Beberapa poin kritis yang harus dipenuhi pada bagian ini adalah masalah tentang jumlah produk dan jenis 
produk yang akan di produksi. Proses ini yang menentukan rencana produksi produk dan warna jenis apa yang akan digunakan.

\section{b. Pretreatment}

Proses pretreatment merupakan proses perlakuan awal pada product sebelum proses pengecatan. Perlakuan yang sering diberikan pada produk plastik sebelum di cat adalah proses pembersihan menggunakan air sabun (fine cleaner) dengan tujuan agar kotoran / zat seperti minyak dapat hilang sebelum produk tersebut masuk ke area pengecatan. Apabila masih terdapat kotoran / zat tersebut akan berdampak terhadap kualitas hasil pengecatan.

\section{c. Dry Oven}

Proses ini bertujuan untuk membuat kondisi produk menjadi kering setelah proses pretreatment. Produk setelah proses pretreatment kondisinya berair, sehingga dibutuhkan proses untuk mengeringkan kondisi produk. Apabila produk tidak sempurna di keringkan akan dapat menimbulkan defect pada produk hasil pengecatan.

\section{d. Spray Booth}

Spray booth merupakan salah satu area dalam proses pengecatan yang berfungsi sebagai tempat untuk atomisasi. Di dalam Spray booth terbagi menjadi beberapa area pengecatan tergantung dari jenis warna yang di produksi. Di dalam pengecatan produk berbahan plastik terdapat dua jenis lapisan cat yaitu lapisan under coat dan lapisan finish coat. Lapisan undercoat berfungsi sebagai warna dasar proses pengecatan, sedangkan untuk lapisan finish coat digunakan untuk mendapatkan warna terakhir sesuai dengan kebutuhan yang diinginkan. Untuk pengecatan jenis electrostatic terdapat lapisan conductive untuk proses electrostatic. Berikut ini contoh konfigurasi Spray pada area booth untuk pengecatan jenis electrostatic (Gambar 12).

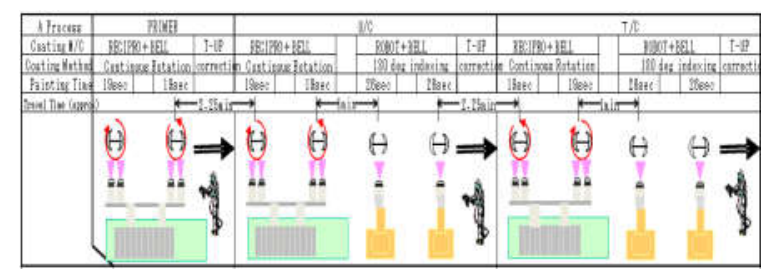

Gambar 12. Konfigurasi Spray booth untuk proses electrostatic
Di dalam area Spray booth terdapat beberapa kriteria yang harus dipenuhi antara lain ruang Spray booth harus benar-benar steril terhindar dari kotoran karena apabila ruang Spray booth kotor akan berdampak terhadap hasil pengecatan. Oleh karena itu setiap masuk ke dalam area Spray booth harus menggunakan baju khusus agar kotoran dari luar tidak masuk ke dalam area Spray booth.

\section{e. Bake Oven}

Setelah produk selesai di cat proses selanjutnya adalah proses curing atau pengeringan produk yang sudah di cat. Proses ini mempunyai peran untuk memastikan kualitas lapisan dari cat kering sempurna, sehingga proses ini mempunyai standard temperature dan waktu sesuai dengan jenis cat yang digunakan.

\section{f. Unloading}

Proses unloading adalah proses menurunkan produk dari hanger yang ada di konveyor dan selanjutnya dilakukan proses pengecekan. Proses pengecekan yang dilakukan merupakan proses pengecekan secara visual yang artinya kualitas yang ditetapkan berdasarkan standard visual yang ada. Untuk beberapa kasus kualitas yang terjadi pada proses pengecekan diperlukan kalibrasi ataupun sosialisasi terhadap standar acuan agar pengecekan yang dilakukan masih sesuai kriteria yang ada.

\section{HASIL DAN PEMBAHASAN}

\subsection{Quality Properties}

\section{a. Quality}

Proses pengecatan produk-produk berbahan plastik tidak selalu menghasilkan produk yang baik namun juga dapat menghasilkan produk yang jelek, hal ini dapat terjadi karena proses yang berlangsung tidak sesuai dengan standard yang ada. Proses pengecatan produk berbahan plastik mempunyai tingkat kesulitan tersendiri dibandingkan proses pengecatan untuk logam. Hal ini disebabkan kerena sifat dari plastik yang cukup beragam mulai dari plastik yang mudah rusak terkena solvent, polaritas yang rendah sehingga susah saat proses pelapisan. 
Dalam hal kualitas proses pengecatan produk berbahan plastik mempunyai kendala antara lain metode pengecekan yang masih dilakukan secara manual yaitu menggunakan standard visual untuk menyatakan produk hasil pengecatan baik atau tidak, sehingga dimungkinkan untuk terjadi perbedaan persepsi dalam hal pengambilakn keputusan terkait hasil dari proses pengecatan. Oleh karena itu diperlukan kalibrasi dan sosialisasi terkait standard visual untuk orang yang melakukan pengecekan hasil pengecatan. Beberapa defect yang sering terjadi pada permukaan hasil proses pengecatan produk berbahan plastik antara lain:

Tabel 1. Jenis-jenis defect pada proses pengecatan produk berbahan plastik

\begin{tabular}{|c|c|c|}
\hline No & $\begin{array}{l}\text { Jenis } \\
\text { Defect }\end{array}$ & Deskripsi \\
\hline 1. & $\begin{array}{l}\text { Kotor / } \\
\text { bintik }\end{array}$ & $\begin{array}{l}\text { Defect kotor atau bintik } \\
\text { umumnya ditemukan pada } \\
\text { lapisan permukaan produk. } \\
\text { kotoran ini ada yang } \\
\text { ditemukan diluar lapisan } \\
\text { (kotoran ruangan) dan ada } \\
\text { juga yang ditemukan di } \\
\text { dalam lapisan seperti } \\
\text { kotoran kerak material cat. }\end{array}$ \\
\hline 2. & $\begin{array}{l}\text { Sagging } \\
\text { / Meler }\end{array}$ & $\begin{array}{l}\text { Defect yang terjadi karena } \\
\text { kelebihan material cat pada } \\
\text { area-area tertentu. } \\
\text { Umumnya terjadi pada } \\
\text { area produk yang } \\
\text { mempunyai bentuk profil } \\
\text { yang tebal / lancip. }\end{array}$ \\
\hline 3. & $\begin{array}{l}\text { Kulit } \\
\text { jeruk/ } \\
\text { orange } \\
\text { peel }\end{array}$ & $\begin{array}{l}\text { Defect yang terjadi karena } \\
\text { visual permukaan hasil } \\
\text { coating menyerupai kulit } \\
\text { jeruk. }\end{array}$ \\
\hline 4. & $\begin{array}{l}\text { Popping } \\
\text { / pin hole }\end{array}$ & $\begin{array}{lrr}\text { Defect } & \text { yang terjadi } & \text { karena } \\
\text { adanya lubang } & \text { seperti } \\
\text { letupan gunung } & \text { pada } \\
\text { permukaan produk. }\end{array}$ \\
\hline 5. & $\begin{array}{l}\text { Lifting / } \\
\text { keriput }\end{array}$ & $\begin{array}{l}\text { Defect yang terjadi karena } \\
\text { cat pada permukaan produk } \\
\text { mengkerut. }\end{array}$ \\
\hline 6. & Crater & $\begin{array}{l}\text { Defect yang disebabkan } \\
\text { karena adanya kawah kecil }\end{array}$ \\
\hline
\end{tabular}

\begin{tabular}{|l|l|l|}
\hline No & $\begin{array}{c}\text { Jenis } \\
\text { Defect }\end{array}$ & \multicolumn{1}{|c|}{ Deskripsi } \\
\hline & & $\begin{array}{l}\text { pada permukaan produk } \\
\text { hasil pengecatan. Crater } \\
\text { umunya terjadi karena } \\
\text { adanya kontaminan pada } \\
\text { permukaan produk sebelum } \\
\text { proses pelapisan. }\end{array}$ \\
\hline
\end{tabular}

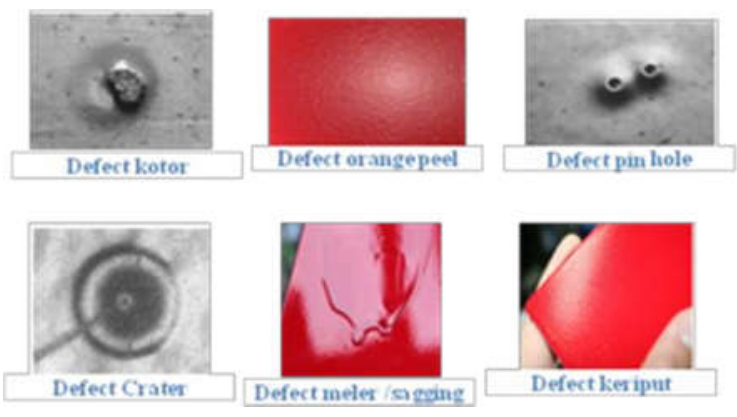

Gambar 13. Jenis-jenis defect proses painting

\section{b. Properties}

Dalam proses produksi pengecatan di industri perakitan sepeda motor tedapat beberapa aktifitas terkait material yang digunakan dalam proses produksi. Sebelum material cat di kirim ke bagian produksi terdapat beberapa system pengujian yang dilakukan untuk mengetahui kualitas dari material cat yang akan digunakan untuk produksi. Pengujaian yang dilakukan pada material cat untuk proses pengecatan produk berbahan plastik dibedakan menjadi dua aktifitas yaitu pengujian untuk rawa material cat dan pengujian pada kualitas lapisan cat hasil pengecatan.

\subsection{Pengujian raw material cat}

Pengujian ini dilakukan untuk mengetahui kualitas dari cat yang akan di kirim ke bagian produksi sebelum digunakan. Aktifitas untuk pengujian ini dilakukan sebelum proyek dimulai untuk kasus warna baru dan untuk penerimaan kualitas cat yang dikirimkan supplier sebelum digunakan untuk proses produksi. Beberapa pengujian yang dilakukan antara lain.

\section{a. Viscocity test}

Merupakan salah satu pengujian yang dilakukan untuk melihat tingkat kekentalan dari material cat. Pengujian viskositas bertujuan 
untuk menghindari kesalahan proses yang disebabkan oleh material cat. Viskositas dalam material cat mempunyai
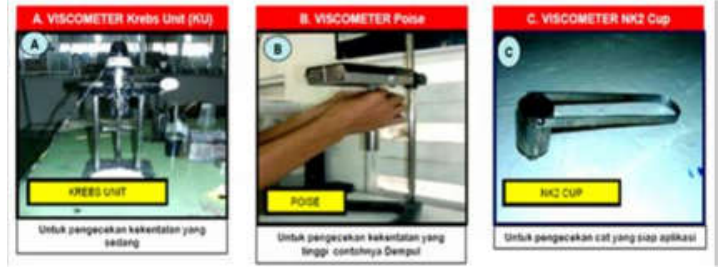

Gambar 14. Jenis-jenis alat viscocity meter

\section{b. NV test}

Non volatile (NV) test merupakan salah satu pengujian yang dilakukan untuk mengetahui solid content (material yang tidak menguap) dari material cat. Nilai ini yang menjadi salah satu pertimbangan material cat dapat di terima atau tidak. Nilai NV ini sangat mempengaruhi kualitas hasil pelapisan. Nilai NV rendah akan berdampak terhadap cat lebih susah menutup permukaan produk hal ini disebabkan komposisi padatan cat yang tidak menguap sedikit. Hal ini dapat mempengaruhi proses pelapisan menjadi berulang karena untuk satu kali proses pelapisan produk belum tertutup sempurna oleh material cat. Berikut ini langkah untuk menguji nilai NV dari suatu material cat.

- Siapkan kertas aluminium untuk menimbang cat original dari supplier

- Timbang berat dari kertas aluminium tersebut dan catat hasilnya.

- Isi aluminium foil tersebut dengan cat seberat 1 gram

- Oven cat tersebut dengan suhu $150{ }^{\circ} \mathrm{C}$ selama 1 jam

- Timbang cat kering dalam aluminium foil

Rumus untuk menghitung nilai NV adalah sebagai berikut:

$$
N V=\frac{\text { brt cat kering }- \text { berat alm foil }}{\text { brt cat basah }} \times 100 \%
$$

Pengujian kualitas film / lapisan

Pengujian ini dilakukan pada produk akhir hasil proses pelapisan. Pengujian ini bertujuan untuk melihat kualitas lapisan yang dihasilkan dari proses pengecatan. Beberapa pengujian yang dilakukan antara lain:

\section{c. Thickness test}

Digunakan untuk mengukur ketebalan cat yang ada pada permukaan produk. Pengujian ini dilakukan untuk memastikan bahwa thickness cat pada permukaan produk sesuai dengan spesifikasi yang ditentukan. Apabila thickness cat tidak sesuai dengan spesifikasi biasanya akan berdampak terhadap hasil visual produk. Thickness cat yang tipis akan menyebabkan visual produk tidak mengkilap dan warna yang dihasilkan tidak sesuai dengan spesifikasi, sedangkan thickness cat yang tebal selain dapat mempengaruhi kualitas visual produk juga dapat menyebabkan inefisiensi pemakaian material cat. Beberapa metode yang digunakan untuk mengukur ketebalan cat pada proses coating antara lain electromagnet thickness dan cutting thickness. Electromagnet umumnya digunakan untuk pengukuran proses coating pada bahan logam sedangkan cutting thickness digunakan untuk proses coating pada produk berbahan plastik.
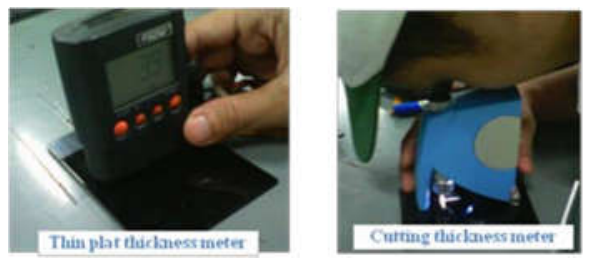

Gambar 15. Jenis-jenis thickness meter

\section{d. Hardness Test}

Pengujian ini dilakukan untuk mengetahui tingkat kekerasan dari lapisan cat. Apabila kekerasan lapisan cat lunak (tidak memenuhi spesifikasi) cat akan mudah tergores. Selain itu kemampuan cat untuk melindungi permukaan produk akan berkurang. Metode yang sering digunakan untuk pengujian kekerasan adalah menggunakan metode gores menggunakan Mitsubishi drawing pencils yang mempunyai tingkat kekerasan tertentu. Symbol tingkat kekerasan pensil dimulai dari 6B yang paling lunak dan $9 \mathrm{H}$ yang paling keras. Symbol urutan kekerasan adalah sebagai berikut : $9 \mathrm{H}$, $8 \mathrm{H}, 7 \mathrm{H}, 6 \mathrm{H}, 5 \mathrm{H}, 4 \mathrm{H}, 3 \mathrm{H}, 2 \mathrm{H}, \mathrm{H}, \mathrm{F}, \mathrm{HB}, \mathrm{B}, 2 \mathrm{~B}$, $3 \mathrm{~B}, 4 \mathrm{~B}, 5 \mathrm{~B}, 6 \mathrm{~B}$. Metode pengujian kekerasan lapisan cat dengan cara menekan permukan lapisan cat menggunakan pensil sesuai dengan gambar [11]. Apabila hasil goresan pensil membekas dipermukaan lapisan cat, maka tingkat kekerasan dari pensil diturunkan satu tingkat, pengujian berhenti jika permukaan lapisan cat tidak ada bekas goresan pensil. Tingkat kekerasan dari lapisan permukaan cat ditentukan dari jenis pensil yang tidak menimbulkan bekas pada lapisan permukaan cat. 


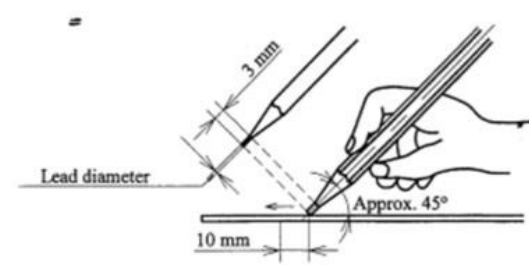

Gambar 16 Metode pengujian kekerasan lapisan cat

\section{e. Adhesion test}

Adhesion test bertujuan untuk mengetahui daya rekat lapisan material cat ke permukaan produk. Pengujian ini dilakukan dengan cara membuat goresan membentuk segi empat sebanyak 100 kotak di permukaan material cat yang akan di uji. Setelah dibuat goresan rekatkan cellopane adhesive tape ke permukaan yang telah digores. kemudian tarik cellopane ke arah belakang. Untuk menentukan hasil dari addesion test dilakukan dengan cara melihat hasil goresan segi empat apakah ada yang terkelupas atau tidak. Apabila ada yang terkelupas kualitas addesive cat ke permukaan produk tidak baik.

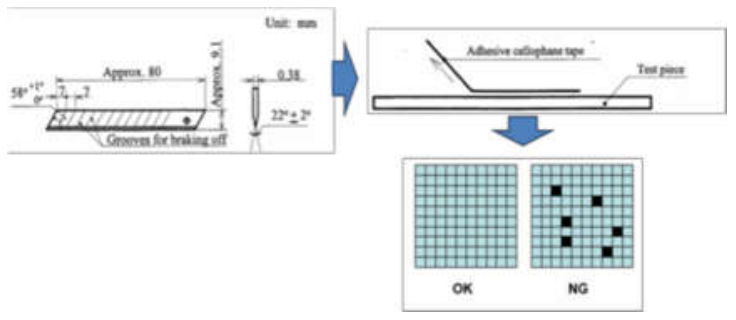

Gambar 17. Metode pengujian adhesion

\section{f. Gloss test}

Pengujian ini bertujuan untuk melihat tingkat kilap dari lapisan permukaan cat. Untuk menguji gloss pada permukaan menggunakan alat yang sering disebut glossmeter. Cara pengujiannya dilakukan dengan cara meletakkan workpieces yang akan diukur di bawah alat ukur seperti gambar 18. Langkah selanjutnya tekan tombol measurement pada tombol alat ukur. Gloss meter umumnya membaca tingkat kilapan benda dalam tiga posisi yaitu sudut $20^{\circ}, 40^{\circ}$ dan $60^{\circ}$.

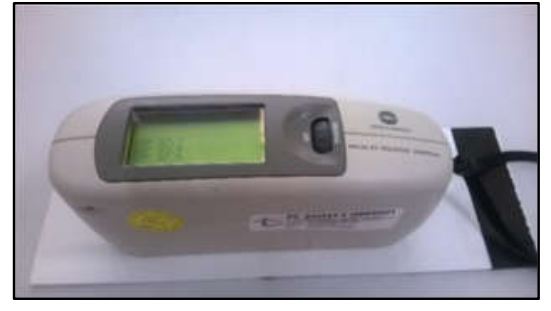

Gambar 18..Alat ukur gloss meter

\section{- Color Matching}

Pengujian ini untuk melihat gradasi warna terhadap master color. Perbedaan warna sering terjadi karena adanya perakitan antar produk menjadi satu sehingga memungkinkan untuk terjadi perbedaan warna antar pertemuan produk. color matching test umumnya menggunakan metode visual mata, namun dalam kondisi tertentu pengukuran perbedaan warna dapat menggunakan alat bantu chromameter. Gradasi warna yang diijinkan adalah 1,5 dari master color.

\section{KESIMPULAN}

Proses pengecatan menjadi salah satu proses manufaktur yang cukup sulit di industri perakitan sepeda motor khususnya untuk pengecatan produk berbahan plastik. Beberapa faktor yang menjadikan proses pengecatan menjadi sulit karena produk berbahan plastik mempunyai sifat-sifat fisik yang sulit untuk dilapisi. Beberapa persoalan yang dihadapi oleh bagian pengecatan antara lain:

\section{Rejection Process}

Terkait dengan rejection proses di bagian pengecatan khususnya pengecatan produk berbahan plastik terdapat beberapa kendala dari segi hasil pengecatan. Hampir $80 \%$ produk yang turun dari line painting harus melewati proses repair terlebih dahulu. Proses repair ini ada yang bersifat remanufacturing ada yang bersifat rework. Proses rework produk hasil pengecatan paling dominan disebabkan karena cacat visual seperti bintik / kotor pada produk hasil pengecatan. Banyak faktor penyebab terjadinya defect bintik, mulai dari kondisi ruang spray booth yang kotor sampai dengan faktor material yang menyebabkan defect bintik pada permukaan produk.

\section{Scheduling Problem}

Permasalahan yang muncul tentang penjadwalan produksi di bagian pengecatan terkait dengan system perawatan pada 
equipment pengecatan. Setiap terjadi pergantian warna beberapa peralatan harus melalui pembersihan terlebih dahulu karena apabila tidak di bersihkan akan berdampak ke warna selanjutnya. Selain itu permasalahan penjadwalan sangat erat hubungannya dengan kualitas produk hasil pengecatan hal ini berarti diperlukan kecepatan perubahan penjadwalan apabila terjadi hasil produksi tidak sesuai dengan rencana awal.

\section{Material Consumption}

Penggunaan teknologi atomisasi dalam proses pengecatan produk berbahan plastik menyebabkan terjadinya overspray ketika proses atomisasi. Over spray yang terjadi pada spray manual menggunakan spray gun dapat mencapai 70\% [3] yang artinya besarnya material yang mampu menempel pada produk hanya sebesar $30 \%$ dari total pemakaian material. Hal ini yang menjadikan efisiensi pemakaian material proses pengecatan menjadi rendah.

\section{VOC (volatile organic compound)}

Volatile organic compond merupakan salah satu parameter yang menunjukan besarnya bahan kimia yang tidak menguap dalam proses pengecatan, parameter ini berhubungan dengan efek gas rumah kaca yang disebabkan adanya penguapan bahan kimia ke udara bebas. Dalam proses pengecatan produk berbahan plastik menggunakan bahan dasar minyak bumi yang terdiri dari beberapa komponen. Komponen yang terdapat dalam material cat sebagian besar menguap ke udara bebas. Maka dari itu untuk dapat meminimalkan volatile organic compound salah satunya dapat dilakukan dengan mengurangi konsumsi material cat. Selain itu VOC dapat di tekan dengan melakukan perbaikan yang berhubungan dengan material cat itu sendiri.

\section{ACKNOWLEDGEMENTS}

Nur Islahudin: staf pengajar di Universitas Dian Nuswantoro program studi teknik industri. Menempuh pendidikan program sarjana di Universitas Pancasila Jakarta jurusan Teknik Industri dan melanjutkan studi Magister di Institut Teknologi Bandung program studi Teknik dan Manajemen Industri. Sebelumnya penulis merupakan seorang praktisi di salah satu perusahaan otomotif selama \pm 9 tahun. Bidang pekerjaan yang pernah ditempati adalah painting plastik dan injection molding. Research area yang diminati antara lain Production System, Quality System, Scheduling System, dan Painting Spray Technology.

\section{DAFTAR PUSTAKA}

[1] Artikel Kementrian Perindustrian, "Kementrian Perindustrian Republik indonesia," 2012.

[2] R. A. Nallicheri, "Automotive Painting: An Economic and Strategic Analysis," Massachusetts Institute Of Technology, Cambridge, Massachusetts, 1994.

[3] S. A. Colbert and R. A. Cairncross, " $A$ computer simulation for predicting electrostatic spray coating patterns," in Powder Technology, 2005.

[4] R. Talbert, Paint Technology Handbook. 2010.

[5] L. P. Bayvel and Z. Orzechowski, Liquid atomization. 1993.

[6] K. D. Weiss, "Paint and coatings: A mature industry in transition," Prog. Polym. Sci., 1997.

[7] C. Schoff, "Painting Problems," in Coatings Of Polymers And Plastiks, 2003.

[8] S. Spieckermann, K. Gutenschwager, and S. $\mathrm{Voß}$, "A sequential ordering problem in automotive paint shops," Int. J. Prod. Res., vol. 42, no. 9, pp. 1865-1878, 2004.

[9] A. Goldschmidt and H. Joachim-streitberger, BASF Handbook on Basics of Coating Technology. Hannover, Germany, 2003.

[10] I. Kolev, "Coatings on Plastiks - Technology Designed for a Wide Range of Solutions," Soc. Vac. Coaters, 2013.

[11] N. Dhafr, M. Ahmad, B. Burgess, and S. Canagassababady, "Improvement of quality performance in manufacturing organizations by minimization of production defects," Robot. Comput. Integr. Manuf., 2006.

[12] L. R. Botelho, J. C. Leite, and J. N. N. Quaresma, "Proposed solution for reduce defects in the process of painting of plastic parts of motorcycle industry," Espacios, 2017.

[13] PT Astra Honda Motor, "Manufacturing Process Painting Plastic,” Qual. Dep., 2000.

[14] PT Murni Cahaya Pratama, "Modul Training Pengetahuan Painting Proses," 2008.

[15] B. A. Graves, "Painting Plastics at HarleyDavidson,” Prod. Finish., 1996.

[16] H. Janik, M. Sienkiewicz, and J. KucinskaLipka, "Polyurethanes," in Handbook of Thermoset Plastiks, 2013.

[17] A. H. Lefebvre and V. G. McDonell, Atomization and sprays. 2017. 